\title{
Factors Related to Clinical Pathway Documentation Among Nurses' at Psychiatric Hospital in South Sumatera
}

\author{
Rianita Citra Tri Sartika ${ }^{1}$, Hema Malini $^{2}$, Ismar Agustin ${ }^{3}$ \\ \{rcitratrisartika@gmail.com ${ }^{1}$, hemamalini@nrs.unand.ac.id ${ }^{2}$, baropagustin@gmail.com ${ }^{3}$ \} \\ Faculty of Nursing, Universitas Andalas, Padang, Indonesia ${ }^{1,2}$ \\ Poltekkes Kemenkes Palembang, Academy of Nursing, Indonesia ${ }^{3}$
}

\begin{abstract}
Clinical Pathway (CP) is one means of integrating health services. In psychiatric hospitals in South Sumatera, it found that the completeness of CP documentation conducted by nurses was still less. This study aims to analyse the description of knowledge, skills, attitudes and work situations of nurses in carrying out the documentation of $\mathrm{CP}$ in the inpatient room. This research type is quantitative with the descriptive analytic approach. The sample of the research was 77 nurses determined by using total sampling technique. There is a set of questionnaires that measured four aspects of the patients. In this study found the knowledge and skills of nurses associated with the implementation and documentation of good CP, while the attitude and work environment are only more than a good part. Recommendations in this research are to maintain and improve the knowledge and skills of nurses, in addition to the need to nurture the attitude of nurses to improve performance and improve work facilities following the needs of nurses in the hospital.
\end{abstract}

Keywords: Health Services, Quality Of Care; Performance Measurements.

\section{Introduction}

In assessing the process of accreditation of a hospital, one of the standards that become the reference is related to the implementation of patient-focused services, known as "patientcentered care." In the patient-centered care approach, so that all health workers can work in an integrated way, the Clinical Pathway (CP) becomes a means of integrating health services [1]. Clinical Pathway (CP) can improve the quality of health services by improving the performance of health practitioners who provide integrated care. With the increase in performance is expected to increase the effectiveness and efficiency of services that impact on improving patient satisfaction on health services [2].

Health services in Indonesia generally tend not to achieve optimal quality, and it requires the government and health service institutions to improve the quality of health services. The quality of health services is unique because the dimensions and indicators can be different among those involved in health services [3]. The quality of health services is highly desirable for every patient and family undergoing treatment. In assessing a quality health service, seven pillars can be used as a reference that is safe, effective, easy, certified, timely, efficient and equitable [4]. 
To improve the quality of health services need efforts both from government and health service institutions. Many programs have been created and run, including the National Health Insurance program or abbreviated (JKN). This program implemented under the Regulation of the Minister of Health of the Republic of Indonesia Number 71, (2013) on Health Services on National Health Insurance (JKN). The JKN program serves as the quality control and cost control for health services in Indonesia, implemented by the Social Security Administering Agency (BPJS) of Health [5]. In 2014 participants OF BPJS reached 52.33\%. In 2015 there was an increase of $61.51 \%$ and in 2016 increased again reached $67.6 \%$ of the total population of Indonesia [6].

In its implementation, the JKN program gets pro support and disagreement, and there is fraud in it. Therefore, as the government's fraud prevention efforts to make a policy of clinical governance. Clinical management consists of the competence and competence of health personnel, clinical audit, and stipulation of claims procedures, application of service standards, clinical service guidelines, and clinical pathway [7]. The clinical pathway was developed to solve the occurrence of fraud in the health insurance system. Ideally, CP has the primary function as a map or reference in the provision of care to patients.

Clinical pathway $(\mathrm{CP})$ is designed to provide details of what to do and provide day-to-day management plans according to health service standards [8]. Clinical pathway (CP), as well as fraud prevention in the JKN program, also plays an essential role in the implementation of the Indonesia Case Base Groups (INA CBG's) tariff in health services. Indonesia Case Base Groups (INA CBG's) is the number of claims paid by BPJS Health to Advanced Referral Health Facility for service packages based on the grouping of disease diagnoses and procedures [9].

[10] Explain that Clinical Pathway is a clinical pathway or known as a treatment line, which has an integrated care path and has a maintenance map; in addition, CP is also used as a tool to manage the quality of care according to the standardisation of health services. Research in China pilots CP implementation in some provinces. The results showed that $\mathrm{CP}$ use and payment reforms proved to improve the quality and affordability of care. Until now the implementation of the program proved to increase patient satisfaction [11]. Research in Korea shows that the application of CP has been shown to decrease LOS and hospitalisation costs [12]. Research in Indonesia that is in Yogyakarta show with the existence of CP there is an improvement in the service process of stroke patient [13].

Currently, the completeness of documenting CP in hospitals still tend to be less. In the inpatient installation of RS PKU Muhammadiyah Bantul stated that from the examination of 35 patient medical records there are only ten medical records that have $\mathrm{CP}$ form. Of the ten medical records that have a CP form none of them is filled [14]. The research conducted by [15] obtained the completeness of the $\mathrm{CP}$ document as a whole only amounted to $33.11 \%$. At the Anutapura hospital in Palu city stated that the compliance of the caregiver to the patient in the documentation on the CP form is right that is reaching $80 \%$. The condition is due to good collaboration among multidisciplinary professions involved in providing care to patients [16]. This study aims to see the description of knowledge, skills, attitudes and work situations that nurses have in documenting clinical pathway in the care room. 


\section{Methodology}

This research uses quantitative research design with the detailed analytic approach. Respondents in the study were 77 nurses who worked in the inpatient ward. Technics of sampling uses a total sampling method in which the entire study population $\backslash$ as a sample of research.

Data collection uses checklists and questionnaires that the researchers made based on various literature that suits the purpose of research. Measurements performed on instrument A consist of several fill columns, including patient identity, signature, monitoring of vital signs, monitoring of patient needs, modal therapy and individual therapy. Measurement of instrument B consists of BI instruments (Knowledge), BII (Skills), BIII (Attitude) and BIV (Working Situation). In the BI instrument by giving the correct answer option which consists of 16 questions regarding the implementation and documentation of CP. In BII instruments, BIII and BIV use Likert-size answer options, and each statement has four answer choices. For BII instrument with a rating of a positive answer $($ never $=1$, sometimes $=2$, often $=3$, always $=4$ ) and a choice of negative answers ie $($ never $=4$, rare $=3$, often $=2$, always $=1$ ). Measurements of BIII and BIV instruments with positive ratings ( strongly disagree $=4$ ) and choice of negative answers (strongly disagree $=4$, disagree $=3$, agree $=2$, strongly agree $=1$ ).

Previous research instruments have been tested for validity. The result of validity test to 20 respondents with provision result of data processing $\geq r$ table (0.468) Based on the result of validity test to $\mathrm{BI}$ instrument, got the result that from 20 questions there are 16 valid questions ( $\mathrm{r}$-value $=0.554-1)$. In the BII instrument obtained from 20 statements, there are 19 accurate statements $(\mathrm{r}=0.505-9.66)$. In the BIII instrument obtained from 15 statements are all valid $(\mathrm{r}$ $=0.470-0.865)$. In the BIV instrument obtained from 30 statements there are 20 valid statements $(r=0.570-0.889)$. Based on the Cronbach Alpha Test, the result is that greater than 0.6 thus all questionnaires are reliable.

The procedures in conducting this research have previously been conducted the ethical test and approved by the Ethics Commission of the Faculty of Medicine Sriwijaya University with number 68/kepkrsmhfkunsri/2018. The ethical principles based on the ethical guidelines of health issued by the National Commission on Health Research Ethics. Furthermore, also equipped with an Informed Consent sheet that contains an explanation of the purpose of the researcher about the overall implementation of the study to the participating respondents as research subjects.

The data obtained from the results of research then processing and data analysis, data processing is done based on four stages of editing, coding, scoring, and data entry that is then analysed using a computer. The researcher then analyses the data. Data analysis includes univariate analysis, conducted to identify the frequency distribution of knowledge, skill, attitude and work situation of the nurse in documenting CP in hospital. The results presented in the form of a distribution frequency table. 


\section{Result}

Table 1. Frequency Distribution of Respondent Characteristics $(n=77)$

\begin{tabular}{lllll}
\hline No & Characteristics of Nurse & Category & f & $\%$ \\
\hline 1 & Age & Early Adult (25-35 year) & 36 & 46.8 \\
& & Late Adult (>35-44 year) & 41 & 53.2 \\
2 & \multirow{2}{*}{ Gender } & Male & 22 & 28.6 \\
& \multirow{2}{*}{ Education } & Female & 55 & 71.4 \\
& \multirow{2}{*}{ Employment Status } & Vocational & 53 & 68.8 \\
& \multirow{2}{*}{5} & Professional & 24 & 31.2 \\
& \multirow{2}{*}{ Working Period } & Civil Servants & 55 & 71.4 \\
& & Non Civil Servants & 22 & 28.6 \\
& & New Employees $(1,5-<2$ year) & 5 & 6.5 \\
\hline
\end{tabular}

Table 1 shows the characteristics of nurses in the hospital, the highest proportion of nurses in the late adult age of the vocational educated female, length of work two years with civil servant status.

From the result of the research, it found that most of the knowledge of nurses in $\mathrm{CP}$ documentation in the inpatient room is good, and more than some of the skills, attitude and work situation of the nurses in documenting CP in good hospitalisation room.

Table 2. Distribution Frequency of Knowledge, Attitude Skills And Work Situation of Nurse $(n=77)$

\begin{tabular}{|c|c|c|c|c|}
\hline No & The Measured variables & Category & $\mathrm{f}$ & $\%$ \\
\hline \multirow[t]{2}{*}{1} & Knowledge & Enough & 10 & 13 \\
\hline & & Good & 67 & 87 \\
\hline \multirow[t]{2}{*}{2} & Skills & Less Good & 29 & 37.7 \\
\hline & & Good & 48 & 62.3 \\
\hline \multirow[t]{2}{*}{3} & Attitude & Negative & 37 & 48.1 \\
\hline & & Positive & 40 & 51.9 \\
\hline \multirow[t]{2}{*}{4} & Work situation & Less Good & 38 & 49.4 \\
\hline & & Good & 39 & 50.6 \\
\hline
\end{tabular}

Table 2 shows that most nurses 'knowledge in CP documentation is good, for nurses' skills, attitudes and work situations in $\mathrm{CP}$ documentation are good.

Table 3. Frequency Distribution of Questionnaire Analysis on Nurse Knowledge

\begin{tabular}{|c|c|c|c|c|}
\hline \multirow{2}{*}{ Knowledge Question Item } & \multicolumn{2}{|c|}{ Correct } & \multicolumn{2}{|c|}{ False } \\
\hline & $\mathrm{f}$ & $\%$ & $\mathrm{f}$ & $\%$ \\
\hline \multicolumn{5}{|l|}{ Implementation of CP } \\
\hline 1. The meaning of word-Clinical Pathway & 49 & 63.6 & 28 & 36.4 \\
\hline 2. Definition of Clinical Pathway & 69 & 89.6 & 8 & 10.4 \\
\hline $\begin{array}{l}\text { 4. Advantages of Clinical Pathway } \\
\text { implementation and documentation }\end{array}$ & 67 & 80 & 6 & 20 \\
\hline \multirow[t]{2}{*}{$\begin{array}{l}\text { 5. The primary purpose of the implementation } \\
\text { and documentation of Clinical Pathway }\end{array}$} & 44 & 57.1 & 33 & 42.9 \\
\hline & 66 & 85.7 & 11 & 14.3 \\
\hline
\end{tabular}




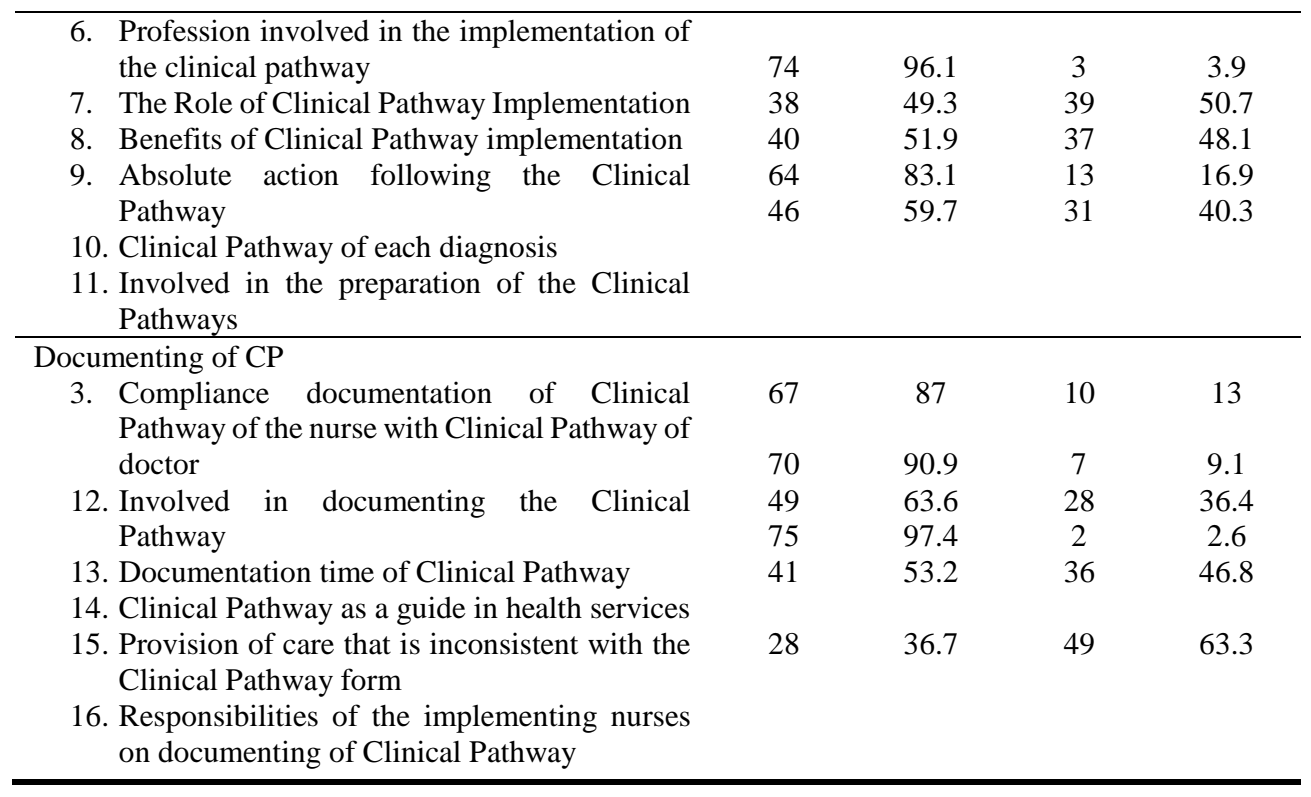

Table 3 shows that the most error in filling out a questionnaire of knowledge is on the question items of nurse responsibility in the implementation of $\mathrm{CP}$, then followed by the question of the benefits of CP implementation.

Table 4. Frequency Distribution of Questionnaire Analysis on Nurse Skills

\begin{tabular}{|c|c|c|c|c|}
\hline \multirow{2}{*}{ Skill Question Items } & \multicolumn{2}{|c|}{ Good } & \multicolumn{2}{|c|}{ Less } \\
\hline & $\mathrm{f}$ & $\%$ & $\mathrm{f}$ & $\%$ \\
\hline \multicolumn{5}{|l|}{ Technical Skill } \\
\hline $\begin{array}{l}\text { 1. I am documenting the implementation of } \\
\text { nursing care on the } \mathrm{CP} \text { document. }\end{array}$ & 57 & 74.0 & 20 & 26.0 \\
\hline $\begin{array}{l}\text { 3. I do not complete the } \mathrm{CP} \text { document on the } \\
\text { patient's assessment checklist. }\end{array}$ & 67 & 87.0 & 10 & 13.0 \\
\hline $\begin{array}{l}\text { 7. I do not complete the } \mathrm{CP} \text { document on the } \\
\text { patient's modal therapy checklist. }\end{array}$ & 49 & 63.6 & 28 & 36.4 \\
\hline $\begin{array}{l}\text { 9. I completed the } \mathrm{CP} \text { document by writing the } \\
\text { name and signing it as the responsible nurse to } \\
\text { the patient. }\end{array}$ & 36 & 46.7 & 41 & 53.3 \\
\hline $\begin{array}{l}\text { 10. I complete the } \mathrm{CP} \text { document by writing the } \\
\text { patient's identity }\end{array}$ & 75 & 97.4 & 2 & 2.6 \\
\hline $\begin{array}{l}\text { 13. I do not complete the } \mathrm{CP} \text { document on the } \\
\text { patient's education checklist }\end{array}$ & 57 & 74.0 & 20 & 26.0 \\
\hline $\begin{array}{l}\text { 15. I completed the } \mathrm{CP} \text { document on checklist } \\
\text { monitoring vital signs on the patient. }\end{array}$ & 65 & 84.4 & 12 & 15.6 \\
\hline $\begin{array}{l}\text { 16. I completed the CP document on checklist } \\
\text { monitoring on the patient's needs. }\end{array}$ & 52 & 67.5 & 25 & 32.5 \\
\hline 19. I completed the CP document on a checklist & 65 & 84.4 & 12 & 15.6 \\
\hline
\end{tabular}




\begin{tabular}{|c|c|c|c|c|}
\hline \multicolumn{5}{|l|}{ Social Skill } \\
\hline $\begin{array}{l}\text { 2. I remind other professions to complete the } \mathrm{CP} \\
\text { documents. }\end{array}$ & 57 & 74.0 & 20 & 26.0 \\
\hline $\begin{array}{l}\text { 4. Co-workers who ignore the CP } \\
\text { documentation make me affected not to } \\
\text { complete the document }\end{array}$ & 70 & 90.9 & 7 & 9.1 \\
\hline $\begin{array}{l}\text { 8. I do not invite other co-workers (nurses) to } \\
\text { complete the CP documentation in the room. }\end{array}$ & 49 & 63.6 & 28 & 36.4 \\
\hline $\begin{array}{l}\text { 11. I work with one professional associate and in } \\
\text { the implementation of CP and its } \\
\text { documentation }\end{array}$ & 59 & 76.6 & 18 & 23.4 \\
\hline $\begin{array}{l}\text { 12. I do not cooperate with other professional } \\
\text { associates in CP implementation and its } \\
\text { documentation. }\end{array}$ & 62 & 80.5 & 15 & 19.5 \\
\hline \multicolumn{5}{|l|}{ Conceptual Skill } \\
\hline 5. I document $\mathrm{CP}$ for every patient & 28 & 36.4 & 49 & 63.6 \\
\hline $\begin{array}{l}\text { 6. I implement } \mathrm{CP} \text { according to the policy of the } \\
\text { leader }\end{array}$ & 41 & 53.2 & 36 & 46.8 \\
\hline $\begin{array}{l}\text { 14. I document } \mathrm{CP} \text { according to the policy of the } \\
\text { leader. }\end{array}$ & 52 & 67.5 & 25 & 32.5 \\
\hline $\begin{array}{l}\text { 17. I am documenting } \mathrm{CP} \text { everytime providing } \\
\text { care to patients }\end{array}$ & 54 & 70.1 & 23 & 29.9 \\
\hline $\begin{array}{l}\text { 18. I am documenting the } \mathrm{CP} \text { just before the } \\
\text { patient will go home }\end{array}$ & 26 & 33.8 & 51 & 66.2 \\
\hline
\end{tabular}

Table 4 shows that most errors are in conceptual skills, where nurses are lacking in documenting CP every day, as well as many nurses, document the CP before the patient return.

Table 5. Frequency Distribution of Questionnaire Analysis on Nurse Attitude

\begin{tabular}{|c|c|c|c|c|}
\hline \multirow{2}{*}{ Attitudes Statement Item } & \multirow{2}{*}{ Good } & \multicolumn{3}{|c|}{ Less } \\
\hline & & $\%$ & $\mathrm{f}$ & $\%$ \\
\hline $\begin{array}{l}\text { 1. I think CP in patients is important to be } \\
\text { implemented and adhered to }\end{array}$ & 44 & 57.01 .00 & 33 & 42.09 .00 \\
\hline $\begin{array}{l}\text { 2. It seems that } \mathrm{CP} \text { facilitates the delivery of health } \\
\text { services, including nursing services }\end{array}$ & 26 & 33.08 .00 & 51 & 66.02 .00 \\
\hline $\begin{array}{l}\text { 3. It seems that CP is not an appropriate means of } \\
\text { collaboration for caregivers such as doctors, } \\
\text { nurses, nutrition analysts and others of health } \\
\text { care in hospitals }\end{array}$ & 31 & 40.03 .00 & 46 & 59.07 .00 \\
\hline $\begin{array}{l}\text { 4. I love the cooperation with other health teams, } \\
\text { in documenting CP in the hospitalisation room } \\
\text { of the hospital. With CP every action is more } \\
\text { planned }\end{array}$ & 31 & 40.03 .00 & 46 & 59.07 .00 \\
\hline $\begin{array}{l}\text { 5. I do not like the implementation of } \mathrm{CP} \text { in the } \\
\text { form of inpatient room of the hospital }\end{array}$ & 26 & 33.08 .00 & 51 & 66.02 .00 \\
\hline $\begin{array}{l}\text { 6. I think every implementing nurse should be } \\
\text { involved in documenting the patient's CP in the } \\
\text { hospital. }\end{array}$ & 26 & 33.08 .00 & 51 & 66.02 .00 \\
\hline $\begin{array}{l}\text { 7. Documentation of CP increases the workload of } \\
\text { nurses }\end{array}$ & 23 & 29.09 .00 & 54 & 70.01 .00 \\
\hline
\end{tabular}


8. Documentation of $\mathrm{CP}$ is also the duty and responsibility of the nurse implementing

$\begin{array}{llll}39 & 50.06 .00 & 38 & 49.04 .00 \\ 26 & 33.08 .00 & 51 & 66.02 .00 \\ 28 & 36.04 .00 & 49 & 63.06 .00 \\ 52 & 67.05 .00 & 25 & 32.05 .00 \\ 57 & 74.00 .00 & 20 & 26.00 .00 \\ 26 & 33.08 .00 & 51 & 66.02 .00 \\ 57 & 74.00 .00 & 20 & 26.00 .00 \\ 57 & 74.00 .00 & 20 & 26.00 .00\end{array}$

9. I think every action has done should be documented both in the form of care and also the form of $\mathrm{CP}$

10. I believe by doing $\mathrm{CP}$ documentation will help the achievement of the goal of CP implementation in hospital

11. I like the existence of hospital policy in $\mathrm{CP}$ implementation and its documentation

12. With $\mathrm{CP}$ every action is more planned

13. I do not like the addition of $\mathrm{CP}$ documentation for patients in inpatient room hospital

14. I do not like when there are new policies that add nurses' work

15. $\mathrm{CP}$ can improve the quality of health services in hospitals 


\begin{tabular}{|c|c|c|c|c|c|}
\hline \multicolumn{6}{|c|}{ Leader Policy } \\
\hline 10. & $\begin{array}{l}\text { Leaders make policies implementation and } \\
\text { documentation CP by involving all } \\
\text { professions that provide care to patients }\end{array}$ & 57 & 74.0 & 20 & 26.0 \\
\hline 18. & $\begin{array}{l}\text { including nurses. } \\
\text { Usually, hospital policy is not known by all }\end{array}$ & 57 & 74.0 & 20 & 26.0 \\
\hline 19. & $\begin{array}{l}\text { subordinates due to lack of socialisation. } \\
\text { The leaders help to improve nurse skills in the } \\
\text { implementation and documentation of CP } \\
\text { with coaching and training }\end{array}$ & 65 & 84.4 & 12 & 15.6 \\
\hline \multicolumn{6}{|c|}{ Form of Leadership } \\
\hline 5. & $\begin{array}{l}\text { Leaders help in solving the problems when I } \\
\text { am facing related to CP documentation. }\end{array}$ & 54 & 70.1 & 23 & 29.9 \\
\hline 12. & $\begin{array}{l}\text { The leaders encourage me to make a } \mathrm{CP} \\
\text { documentation like the example is given }\end{array}$ & 46 & 59.7 & 31 & 40.3 \\
\hline 15. & $\begin{array}{l}\text { The head of the room teaches and } \\
\text { exemplifies matters relating to the workplace } \\
\text { and CP documentation. }\end{array}$ & 13 & 16.9 & 64 & 83.1 \\
\hline 16. & $\begin{array}{l}\text { The leader does not give me any feedback } \\
\text { regarding the CP documentation }\end{array}$ & 5 & 6.5 & 72 & 93.5 \\
\hline 17. & $\begin{array}{l}\text { Leaders listen to my complaints about } \mathrm{CP} \\
\text { documentation }\end{array}$ & 59 & 76.6 & 18 & 23.4 \\
\hline \multicolumn{6}{|c|}{ Working Conditions } \\
\hline & $\begin{array}{l}\text { The workplace environment condition of the } \\
\text { nurse is excellent and comfortable }\end{array}$ & 59 & 76.6 & 18 & 23.4 \\
\hline 14. & $\begin{array}{l}\text { The existence of clear working procedures in } \\
\text { carrying out every work of nurses }\end{array}$ & 49 & 63.6 & 28 & 36.4 \\
\hline 20. & $\begin{array}{l}\text { I feel comfortable with all the policies in the } \\
\text { hospital }\end{array}$ & 52 & 67.5 & 25 & 32.5 \\
\hline
\end{tabular}

Table 5 shows that the work situation is still lacking, especially in the work facility where the nurses feel the facilities in the room still do not meet the needs of the nurses, besides the leadership where the head of the room is still less taught and exemplified in the implementation and documentation of $\mathrm{CP}$.

\section{Discussion}

The result of the research on the nurse's knowledge in implementing and documenting mostly in the right category $(87 \%)$. Almost all nurses can answer correctly every item of the question posed. However, on the question items on the responsibility of the nurse as well as the benefits in the implementation and documentation of $\mathrm{CP}$, there are still many nurses who answered wrongly on both items of the question. The high number of nurse knowledge is supported because the application and documentation of $\mathrm{CP}$ are not difficult to understand let alone fill this form by merely filling the checklist on the form $\mathrm{t}$. The CP team also socialised the implementation and documentation in the inpatient wards to the implementing nurses. Besides, CP is also still as a new approach and only implemented in early 2017 as the assessment of accreditation at the hospital.

Research conducted [17] obtained knowledge of nurse which is almost the same percentage for good category and less $(52.3 \%$ and $47.7 \%)$. Assessment of the nurse's knowledge is about 
documenting nursing care in the inpatient room. Another study conducted [18] is more than some knowledge of nurses in good category (54.4\%), but not a few nurses with insufficient knowledge. In this study, the assessed knowledge is about patient safety. In contrast to some of the above studies, research conducted by [19] found that nurses with knowledge in both categories were only $29.0 \%$. In this study assess the knowledge of nurses in the handling of emergency patients. The low numbers are due to difficult topics and require specialised training and seminars on the topic.

[20] states that knowledge is a process by using the senses that someone does to a particular object that can produce a skill. [21] states that knowledge is the result of human sensory, or results to know someone of the object through its senses, namely the eyes, nose, ears and so on.

Many factors influence one's knowledge, [22] states that six factors influence one's knowledge of age, education, mass media, social, culture, economy, environment, and experience. When looking at the seven factors that influence the knowledge, the nurses at the hospital in this study have a reasonably different factor that can be seen from the characteristics of nurses. However, with the information and socialisation done are significantly increase the knowledge of nurses about the implementation and documentation of $\mathrm{CP}$ in the inpatient room of the hospital.

The result of research on nurse skill implementer in applying and documenting more than half of nurses have a good skill (62.3\%). Quite high nursing skills in CP documentation in general because of CP documentation is not that is too difficult. Nurses only need to checklist every item of care provided to patients every day following CP format that has been provided. Technically skill and social skills of the average nurse have excellent skills. However, in the conceptual skill that is on the item where the nurse documenting $\mathrm{CP}$ every day still tend to be less, besides the nurse documenting CP just before the patient goes home also it has high enough performance.

Research conducted [23] more than some nurses have good skills (89.90\%). In this study, the nurse's job skills are generally following their roles and duties as an implementing nurse. The high nursing skills of the hospital's nurses are in line with the programs and policies of hospitals that support and facilitate nurses to improve their knowledge and skills through training and seminars both within and outside hospitals.

Skill is the ability to do a job that only obtained from practice, either through practice or through experience. Skill is also a person's ability to complete tasks assigned to him Hasibuan (2000) in [24]. [25] also mentions that skills are the ability to operate a job that is easy and careful that requires basic skills. Thus, skills can be interpreted as a capability that a person needs in performing a task or a job efficiently and carefully and obtained through training or experience.

Concerning the concept of work, Paul and Blanchard (1986) in [26] stated that three skills must be owned either as a manager or as executor. First, technical skill is the skill to use the knowledge, methods, techniques, and tools needed to carry out specific jobs gained from experience, education, and training. Secondly, social skills are skills in working with others, motivating others that include an understanding of motivation and effective leadership implementation. The third, conceptual skill is the skill to understand the complexity of the organisation as a whole. Such skills enable a person to act accordingly and in harmony with the organisation's overall objectives rather than the ability-building factor. From the results of research conducted, the average nurse has a useful skill in technical skills, social skills and conceptual skills in documenting CP in the inpatient room of the hospital.

The result of the research on the attitude of the nurse in implementing and documenting $\mathrm{CP}$ in the positive and negative category is almost the same (51.9\% and $48.1 \%$ ). In other words, 
some implementing nurses have negative attitudes in $\mathrm{CP}$ documentation, and some have a positive attitude in documenting $\mathrm{CP}$ in the inpatient room of the hospital. From the result of attitude questionnaire analysis, the average nurse is confident on the $\mathrm{CP}$ benefits in general, but on the other hand, the negative attitude is quite high because the nurses feel with the policy regarding the implementation and documentation of $\mathrm{CP}$ increasing the workload of the nurses in the inpatient room.

The study by [27] mentions that more than half of nurses are good (67.5\%). In this study attitudes assessed are about the implementation of patient safety standards in hospitals. An excellent attitude to the nurse is because the nurse is aware of the importance of applying patient safety standards in the hospital. [28] states that only $4 \%$ of nurses have a good attitude, 50.5\% are moderate, and $30.5 \%$ are unfavourable. This study assessed the attitude of nurses in treating patients who were suspected or diagnosed avian flu.

According to the researcher's analysis, the attitude of the nurses depends heavily on the benefits and consequences of the actions performed by the nurse. Nurses tend to be cynical about things that can risk themselves. Conversely, the nurse will be confident for the actions that provide benefits and do not provide the work risk to the nurse excessively.

The result of the research on the nurse's work situation in the application and the documentation of more than some amount is in good category $(50.6 \%)$. In other words, more than a few nurses have an excellent working situation in CP documentation although it does not vary much with nurses who have poor work situations. The working situation, especially at work facilities where the nurses consider existing facilities in the room still less meet the needs. Besides the leadership pattern of the room is also still lacking in teaching and giving examples to the nurses in documenting $\mathrm{CP}$ in the inpatient room.

Results of research conducted by [29] mentioned that most nurses feel comfortable in the work environment of the emergency department (71\%). This study assessed the complex working environment of working hours, noise, hospital regulations, work demands, social relationships, temperature, lighting, and sound in the work environment. The availability of excellent facilities in the nursing workplace enhances the nurse's satisfaction with their work environment.

The work environment is a situation where the environment in which a person works. The work environment includes working relationships, work facilities, leader policies, leadership patterns and working conditions [30]. The work environment is everything that is around the workers and can affect in carrying out the tasks that are charged [25]. The work environment is also anything that is in the environment that can affect either directly or indirectly a person or group of people in performing their duties [31]. From the above definition can be seen that the work environment is a situation where a person works, both physical situations that can be observed directly or non-physical situation that can not be observed directly.

Good knowledge, skills, attitudes and working situations for nurses are essential. With the four items are expected nurse performance that can be increased. Knowledge, skills, and attitudes are the standards of competence that must be possessed by professionals including nurses. This standard of competence should always be maintained and nurtured to further improvement of performance. Besides, it is necessary also an excellent working situation to support the improvement of the performance of professional nurses. 


\section{Conclusion}

The result of research on knowledge, skill, attitude and work situation of nurse that got most of the knowledge of nurse executing in the documentation of $\mathrm{CP}$ is good. While the skills, attitudes and work situations of the nurse in $\mathrm{CP}$ documentation have better skills and more than other numbers. The existence of a description of the knowledge, skill, attitude and work situation of the nurse in $\mathrm{CP}$ documentation can be used as a reference in evaluating the implementation of clinical pathway policy in hospital. The researcher recommends to hospital management to maintain and improve the knowledge and skills of nurses, besides the need to nurse the attitude of nurses to improve performance and improve work facilities following the needs of nurses at the hospital. For implementing nurses, it is expected to further improve the positive attitude in the implementation of $\mathrm{CP}$ in hospitals given the number of benefits in the implementation of the policy. Working with sincerity can improve morale in working.

\section{References}

[1] Firmanda, Dody. Clinical Pathways Rumah Sakit. Jakarta : RSUP Fatmawati. (2011).

[2] Djasri, O. H. Peran Clinical Pathways dalam Sistem Jaminan Sosial Nasional Bidang Kesehatan 1, 3-7. (2013).

[3] Al-Assaf. Mutu Pelayanan Kesehatan Perspektif Internasional. Jakarta : EGC. (2009).

[4] Ayanian, J. Z., \& Markel, H. Donabedian's Lasting Framework for Health Care Quality. New England Journal of Medicine, 375(3), 205-207. https://doi.org/10.1056/NEJMp1605101. (2016).

[5] Peraturan Menteri Kesehatan RI. Undang-Undang No. 71 Tahun 2013. Pelayanan Kesehatan Pada Jaminan Kesehatan Nasional. Jakarta. (2013).

[6] BPJS Kesehatan. Peranan BPJS Kesehatan Dalam Peningkatan Pelayanan Kesehatan. Disampaikan Dalam Rakerkernas BPSJ. Diakses Pada Web www.BPJS-kesehatan.go.id. (2017).

[7] Peraturan Menteri Kesehatan RI. Undang-Undang No. 36 Tahun 2015. Tentang Pencegahan Kecurangan. Jakarta. (2015).

[8] Kementerian Kesehatan RI. Pedoman Penyusunan Standar Pelayanan Kedokteran. Jakarta : Direktorat Jendral Bina Upaya Kesehatan. (2014).

[9] Peraturan Menteri Kesehatan RI. Undang-Undang No. 52 Tahun 2016. Standar Tarif Pelayanan Kesehatan dalam Penyelenggaraan Program Jaminan Kesehatan. Jakarta. (2016).

[10] Huang, Z., Lu, X., \& Duan, H. Using Recommendation To Support Adaptive Clinical Pathways. Journal of Medical Systems, 36(3), 1849-1860. https://doi.org/10.1007/s10916-010-9644-3. (2012).

[11] Cheng, T.-M. A Pilot Project Using Evidence-Based Clinical Pathways And Payment Reform In China's Rural Hospitals Shows Early Success. Health Affairs, 32(5), 963-973. https://doi.org/10.1377/hlthaff.2012.0640. (2013).

[12] Sung, K. H. et al. Application Of Clinical Pathway Using Electronic Medical Record System In Pediatric Patients With Supracondylar Fracture Of The Humerus: A Before And After Comparative Study. BMC Medical Informatics and Decision Making, 13(1), 87. https://doi.org/10.1186/1472-6947-13-87. (2013).

[13] Pinzon, R., Asanti, L, \& Widyo. Clinical Pathway Dalam Pelayanan Stroke Akut: Apakah Pathway Memperbaiki Proses Pelayanan?. Jurnal Manajemen Pelayanan Kesehatan, 12(1), 20 23. (2009).

[14] Sari dan Sundari. Evaluasi Implementasi Clinical Pathway Krisis Hipertensi Di Instalasi Rawat Inap RS PKU Muhammadiyah Bantul. Universitas Muhammadiyah Yogyakarta.http://mmr.umy.ac.id/artikel/proceeding/. (2017). 
[15] Nurfaridah, dkk. (2014). Evektifitas Pelayanan Selama Penerapan Clinical Pathway Skizofrenia Rawat Inap Di RSUP Sardjito Yogyakarta.Universitas Gadjah Mada. Jurnal Manajemen Pelayanan Kesehatan, Vol. 17, No. 1. (2014).

[16] Mutiasari dkk. Evaluasi Pengembangan Dan Penerapan Clinical Pathway Kasus Stroke Iskemik Di Rumah Sakit Anutapura Kota Palu.Universitas Gadjah Mada. ISSN : 2460-9684. vol: 02 - no 02. (2017).

[17] Nuryani, Dwi dan Hartati Sri Tutik. Pengetahuan dan Sikap Perawat Terhadap Kelengkapan Pendokumentasian Asuhan Keperawatan di Rumah Sakit. Universitas Indonesia. (2014).

[18] Kuncoro, Teguh. Hubungan antara pengetahuan, Sikap, dan Kualitan Kehidupan Kerja Dengan Kinerja Perawat Dalam Penerapan Sistem Keselamatan Pasien Di Rumah Sakit. Program Studi Magister Kajian Administrasi Rumah Sakit. Universitas Indonesia. (2012).

[19] Laoh, Mermy Joice dan Rako Konny. Gambaran Pengetahuan Perawat Pelaksana Dalam Penanganan Pasien Gawat Darurat Di Ruangan IGDMedik RSUP Prof. Dr. R. D. Kandou Manado.Poltekkes Kemenkes Manado. Juiperdo, vol 3, no. 2. (2014).

[20] Hidayat, A. Riset Keperawatan dan Tehknik Penulisan Ilmiah. Jakarta : Salemba Medika. (2007).

[21] Notoadmodjo, Doekidjo. Metodologi Penelitian Kesehatan. Jakarta : Rineka Cipta. (2010).

[22] Mubarak, WI. Ilmu Kesehatan Masyarakat Teori dan Aplikasi. Jakarta : Salemba Medika. (2009).

[23] Budiawan, dkk. Hubungan Kompetensi, Motivasi dan Beban Kerja Dengan Kinerja Perawat Pelaksana Di Rumah Sakit Jiwa Provinsi Bali.Public Health and Preventive Medicine Archive. Universitas Udayana. (2015)

[24] Istikomah, Asih Nor. dkk. Pengaruh Keterampilan Kerja, Kompensasi dan Disiplin Kerja Terhadap Kinerja Perawat. Universitas Diponegoro. E-Journal-sl.undip.ac.id/index.php/. 1-12. (2014).

[25] Robbins, Stephen P dan Timothy A. Judge. Perilaku Organisasi. Jakarta : Salemba Empat. (2009).

[26] Rahman, Albert, Wibi. Pengaruh Kompetensi dan Lingkungan Kerja Terhadap Kinerja Perawat Bagian Rawat Inap Pada Rumah Sakit Umum Daerah (RSUD). Petala Bumi Pekanbaru. Fakultas Ekonomi. E-Journal Universitas Riau. Jom FEKON Vol.2 No.1. (2015).

[27] Setiyajati, A. Pengaruh Pengetahuan dan Sikap Perawat Terhadap Penerapan Standar Keselamatan Pasien di Instalasi Perawatan Intensif RSUD Dr. Moewardi. Universitas Sebelas Maret Surakarta.perpustakaan.uns.ac.id. (2014).

[28] Yuliastuti, Iing. Pengaruh Pengetahuan, Keterampilan Dan Sikap Terhadap Kinerja Perawat Dalam Penatalaksanaan Kasus Flu Burung di RSUP.H.Adam Malik. Sekolah Pascasarjana. Universitas Sumatera Utara. (2007).

[29] Lumingkewas, Mega. Hubungan Kondisi Kerja Dengan Stres Kerja Perawat Dirungan Intasalasi Gawat Darurat Medik RSUP Prof. Dr. R. D. Kandou Manado.Universitas Sam Ratulangi. EJournal Keperawatan (e-Kp) Volume 3 Nomor 3. (2015).

[30] Mangkunegara, A.A. Anwar Prabu. Manajemen Sumber Daya Manusia Perusahaan. Bandung : PT Remaja Rosdakarya. (2005).

[31] Basuki dan Susilowati. Dampak Kepemimpinan dan Lingkungan Kerja Terhadap Semangat Kerja.Jurnal JRBI.Vol 1 No 1. Hal 31-47. (2005). 